\title{
PERSONALITY TRAITS, BIOGRAPHICAL VARIABLES, AND ATTITUDES TO MONEY AMONG AUSTRIAN STUDENTS
}

\author{
REINHARD FURTNER ${ }^{1}$
}

\begin{abstract}
Previous research in many parts of the world has linked personality traits and biographical variables to certain money-related-attitude factors, while the situation in Austria has hardly been investigated so far. The purpose of this study was to identify possible relations between personality traits, biographical variables (independent variables), and money attitude factors (dependent variables) in Austria.

In this quantitative study, the NEO Five-Factor Inventory (NEO-FFI, measuring personality traits), the Money Attitude Scale (MAS, measuring money attitudes), as well as self-constructed biographical items were used. Data was collected through an online questionnaire, which was answered by 83 Austrian business education students. The results were analyzed with descriptive and inferential methods.

The personality dimensions "openness to experience" and "agreeableness," as well as the biographical factor "gender," significantly influence the money attitude "power-prestige." The personality dimensions "neuroticism" and "conscientiousness" are significantly associated with the money attitude "anxiety." Thus, gender and certain personality dimensions could act as predictive factors for pronounced power-oriented or anxiety-oriented money attitudes.
\end{abstract}

KEYWORDS: money attitudes, personality traits, $M A S, N E O-F F I$

1 Reinhard Furtner is a student of the $\mathrm{PhD}$ Program in International Economic Relations and Management at the University of Applied Sciences Burgenland in cooperation with the University of Economics in Bratislava, e-mail: 1719001129@fh-burgenland.at. 


\section{INTRODUCTION}

Money (albeit lacking real intrinsic value nowadays) represents countless different objects; it can be exchanged into nearly anything else (Harari 2017). It generates various emotions, meanings, and feelings (e.g. evil, power, achievement, respect, anxiety, freedom, love, and security) in human individuals (Yamauchi - Templer 1982) as it is nowadays considered to represent the "most emotionally meaningful object" in our lives (Krueger 1986).

Research about attitudes to money ("money attitudes") has gained increasing attention over past decades. Two lines of research can be distinguished: One focuses on the development of psychometric instruments for measuring different money attitudes (e.g. Money Attitude Scale, Money Beliefs and Behavior Scale); the other examines the effect of individual differences (e.g. demographic variables or life experiences) as predictors of money attitudes (Lim et al. 2003). Previous research in many parts of the world (primarily in Northern America, Southern America, and Asia) has indicated that age, gender, educational level, and ethnic background could be considered relevant factors for predicting money attitudes ( $\mathrm{Li}$ et al. 2009). There exists, however, sparse literature with a focus on relevant predictors in Austria (Furtner 2017; Nowak - Pani 2013), the situation which is addressed in this article. The findings are also compared to the results of related articles that focus on potential predictors in other countries.

The goals of this article are (a) to investigate if personality traits (neuroticism, extraversion, openness to experience, agreeableness, conscientiousness) or biographical variables (gender, age, net income, total budget, household wealth) predict money attitudes (power-prestige, retention-time, distrust, anxiety) for Austrian business education students, and (b) to point out possible implications of these results for business or personal purposes.

The remainder of the article is structured as follows: First, the related literature is summarized and the applied methodology is described. Then, results are presented and discussed. Finally, the article is completed with concluding remarks.

\section{LITERATURE REVIEW}

\section{The economic and the psychological view of money}

The traditional economic approach defines money as a medium of exchange and as a unit of account based on the axioms of homoeconomicus and the 
expected utility model (functional definition). Money further acts as a form of value storage and as the standard of deferred payment. This concept presupposes dispassionate and logical-thinking agents, which in theory strictly aim at utility and profit-maximization in financial matters, e.g. in investment decisions (Furnham - Argyle 2013). Empirical studies about investment decisions show that those basic axioms are constantly violated; e.g. behavioral finance research has indicated the existence of irrational effects like framing and anchoring (Kahneman 2003).

Crucial weaknesses of the homo-economicus and expected-utility models are their disregard for relevant factors concerning the human perception of money and investment decision problems. These concerns influencing biographical factors (e.g. age, education), personality factors (e.g. illusion of control, personality traits), and cognitive factors (e.g. finance-related knowledge) as well as individuals' social networks (Adelt - Feldmann 2017; Günther - Detzner 2009; Harrison 1994; Müller 1995; Wärneryd 2001).

\section{Money attitudes}

Individuals generate a stable self-concept (or an identity) which represents a specific image (broader values, attitudes, and specific desires) about themselves (Sommer 2007) during socialization (Furnham et al. 1994; Mohamad et al. 2006). Attitudes are embedded in this self-concept in connection to an individual's emotional position, which is related to internal expectations and valuation, whereby the focus is on persons, ideas, or items (Six 2009). Those experiencebased attitudes (states of readiness in a mental and neural context) influence an individual's view of related objects and situations (Allport 1935). They are learned predispositions that emerge as consistent and persistent responses to certain objects, either favorable or unfavorable (Fishbein - Ajzen 1975).

Several meta-analyses have indicated that attitudes are predictors of behavior in some cases, yet not always: The extent of the relationship depends on the attitude-behavior field that is analyzed (Ajzen - Fishbein 2014; Six 2009) and which is influenced by factors like prior experience, accessibility to attitudes, confidence, attitude change, attention, and exposure to information and past behavior (Albarracin et al. 2014). Fazio's MODE-model (motivation, opportunity, determinants) underpins these findings in theory (Ajzen - Fishbein 2014; Fazio 1990; Fazio - Olson 2014).

Attitudes represent multiple dimensions of positive and negative emotions (Medina et al. 1996) linked to money. Such money attitudes that refer either to internal aspects (feelings, strivings, emotions, fantasies, fears, wishes, 
distortions, denials, and impulses) or to external forms of valuation (comparison, measurement, reference frame, social status) can be described as follows:

- Money is subjectively evaluated in the eye of the beholder: It is considered to represent status, acts as a measurement of achievement, or may even be perceived as an evil object (McClelland 1967).

- Individuals link money to different feelings, significance, and strivings. It is the emotionally most meaningful object for humans; only food and sex are close competitors (Krueger 1986). A wide range of emotion related nouns like respect, love, anxiety, happiness, helplessness, fear, and distrust are associated with money (Rubinstein 1981).

- Money also acts as a frame of reference when individuals examine their everyday lives (Tang 1992).

- Money attitudes cover social status and personal contentment and they influence individual behavior related to monetary decisions (Taneja 2012).

- Money attitudes are related to our individual fantasies, fears, and wishes. Therefore, money can be linked to distortions and denials; it is connected with our impulses or defense against impulses (Furnham - Argyle 2013).

\section{Money Attitude Scales}

Various scales for measuring money attitudes have been developed, while the most relevant contributions reach back to the 1960s (Taneja 2012). Famous examples include the Money Attitude Scale (MAS) (Yamauchi - Templer 1982), the Money Beliefs and Behavior Scale (MBBS) (Furnham 1984), the Money Importance Scale (MIS) and the Money Ethical Scale (MES) (Tang 1992), which have been widely applied in relevant research activities during the last decades (Jhang 2018). Although the abovementioned scales have gained numerous applications recently, a further focus is on reviewing work related to the MAS, and this goal forms one pillar of this research project.

Yamauchi and Templer developed the MAS as a standardized instrument for measuring money attitudes on a seven-point Likert scale. Based on the work of widely accepted psychotherapists and economists (e.g. Freud), three broad content areas of psychological money aspects (security/insecurity, retention, power-prestige) were identified, leading to 62 subsequently developed items. The first scree test indicated five substantive factors, which explained $33.6 \%$ of variance (power-prestige, retention-time, distrust, quality and anxiety). After removing the quality dimension from the test (quality items and power-prestige items showed no significant difference), 29 items remained. In total, the MAS showed a Cronbach's $\alpha$ value of 0.77 , while retest reliability was measured at 0.88 
(Yamauchi - Templer 1982). Later repetitive MAS testing indicated acceptable levels of reliability (Engelberg - Sjöberg 2006).

The characteristics of the four MAS-related factors can be summarized as follows (Blaszczynski - Nower 2010; Yamauchi - Templer 1982):

- Power-Prestige: Money is perceived as a tool of power, which is used to impress and influence others; it also works as a measure of success.

- Retention-Time: The use of money is planned and monitored carefully with a strong future-oriented focus.

- Distrust: Money-related situations are connected with hesitancy, suspicion, and doubt.

- Anxiety: Money acts as a source of anxiety and as a means of the prevention of anxiety.

Although the original MAS was tested on a seven-point Likert scale, fivepoint Likert scales (from strongly disagree to strongly agree) have also been used in quantitative studies (Chi - Banerjee 2013).

\section{Predictive factors in relation to money attitudes}

Regarding money attitudes, the predictive factors age, gender, educational level, and cultural background have been identified ( $\mathrm{Li}$ et al. 2009). Besides these biographical factors, personality and attitudinal factors are also of relevance (Mitchell - Mickel 1999). The current study focuses on biographical (gender, age, net income, total budget, household wealth) and personality factors (personality traits) as potential predictive factors for money attitudes.

As shown in detail in Appendix A, gender is a strong predictor of money attitudes (e.g., females show a more anxious and males a more power-oriented money attitude). Further predictive biographical factors like income, education, religion, cultural background, age, and occupational background are also presented in Appendix A: For example, cultural differences occur regarding the retention-time factor (Mexican-Americans vs. Anglo-Americans), and a power orientation tends to be stronger for private sector workers (private sector workers vs. governmental employees) (Chi - Banerjee 2013; Furnham 1984; Furnham - Okamura 1999; Hanashiro et al. 2004; Medina et al. 1996; Roberts - Sepulveda 1999; Sabri et al. 2006).

Empirical results (summarized in Appendix B) indicate that personality factors are predictors of financial behavior, which - at least to a certain extent is influenced by money attitudes (Ajzen - Fishbein 2014; Six 2009): Extraverted individuals are more liable to own shares or have credit card debt. Individuals 
with a conscious-pronounced money attitude, in contrast, rather avoid credit card debt (Brown - Tailor 2014). While normal customers tend to focus on the security dimension of money, compulsive spenders show stronger poweroriented money attitudes (Belk 1985; Brown - Taylor 2014; Donnelly et al. 2012; Furnham - Okamura 1999; Hanley - Wilhelm 1992; Lau 1998; Wong - Carducci 1991). Compulsive spending has been found to be influenced by agreeableness and neuroticism (Ratnawat - Borgawe 2019). As most of the studies in this field are based on student samples, the findings are of a suggestive character for the general population (Baker - Hagedorn 2008).

\section{Personality traits}

The human personality is the result of stable patterns in the context of actions, feelings, and thoughts. These patterns remain consistent in different situations. Originating from the Big Five approach, which emerged from trait theory, personality can be quantified (McCrae - John 1992 cited after McCrae - Costa 2008). Based on this framework, the standardized NEO-FFI measures the five personality traits/dimensions neuroticism, extraversion, openness to experience, agreeableness, and conscientiousness using a five-point Likertscale. Furthermore, the NEO-FFI dimensions have been replicated many times in the past and the underlying concept is widely recognized in the scientific community (Borkenau - Ostendorf 2008).

\section{METHODOLOGY}

\section{Participants}

In order to identify relevant factors that allow us to predict the money attitudes of business education students in Austria, a sample group of 83 students from the Business Education Master's Program at the Vienna University of Economics and Business (WU) responded to the three-part online survey in 2017. The sampling procedure was carried out on the basis of a population of 95 master students (only 83 students were available during the testing sessions) with an Austrian sociocultural background. The age of the participants ranged from 22 to 52 years (Mean $-M_{\text {Age }}=29.12$; Standard Deviation $-S D_{\text {Age }}=7.60$ ), 64 of whom were female. As the master's program represents a special track for students who work full time, employment status ranged from non-working 
to fully employed with monthly net incomes (per person) of up to EUR 3,000 $\left(M_{\text {Netncome }}=1,090.36, S D_{\text {NetIncome }}=744.84\right)$. Additionally, the total monthly budget of respondents, including net income and other sources of income (e.g. grants, monetary parental support, or other benefits, $M_{\text {Budget }}=1,402.41, S D_{\text {Budget }}=667.31$ ) and household wealth $\left(M_{\text {Wealth }}=90,277.11, S D_{\text {Wealth }}=80,892.18\right)$ were queried in EUR.

The sample was not representative for the Austrian population, especially due to the nature of the student sample, the majority of female respondents, and the relatively young age structure of the sample. Moreover, 2017 monthly net income in Austria was about EUR 2,200 per person based on a 12-month basis (Statistik Austria - Bundesanstalt Statistik 2017), which was approximately double the monthly net income of the student sample.

\section{Measures}

The German-language online survey was comprised of three parts:

- NEO Five-Factor Inventory (NEO-FFI), 60 items (Borkenau - Ostendorf 2008)

- Money Attitude Scale test (MAS), 29 items, translated from English into German (Yamauchi - Templer 1982)

- Five self-developed biographical items (gender, age, net income, total budget on a monthly basis, household wealth in total)

For this study, a five-point Likert-scale-based MAS (corresponding to the five-point Likert-scale-based NEO Five-Factor Inventory, NEO-FFI) was used for the following reasons:

- The general focus of the standardized MAS allows the broad and comprehensive measurement of individual money attitudes, since it has well-tested validity and high reliability (Blaszczynski - Nower 2010).

- This test has been used on different ethnic samples for decades, whereby its broad applicability has clearly been indicated (Medina et al. 1996; Roberts - Jones 2001). The original MAS was developed based on a sample of the ethnically mixed population in Los Angeles and Fresno (Yamauchi-Templer 1982). Testing in other countries has supported its broad applicability; e.g. in Singapore (Lim - Teo 1997), Mexico (Roberts - Sepulveda 1999), and Sweden (Engelberg - Sjöberg 2006).

- The MAS is in accordance with the Money Beliefs and Behavior Scale (MBBS); both well-recognized tests show highly comparable dimensions of money attitudes (Roberts - Sepulveda 1999). 


\section{Statistical methods}

First, the sample characteristics were analyzed based on descriptive measures. Next, multiple linear regression analysis (using the ordinary least squares method) was conducted to determine potential predictive factors of money attitudes: To find the most significant relations, the group sequence was varied and regression analyses were processed for each of the four dependent MAS factors. The same test supervisor conducted the survey during five testing sessions, giving standardized instructions each time for the pretested online survey. Total Cronbach's $\alpha$ indicated sufficient internal consistency reliability with values of 0.69 for the MAS and 0.76 for the NEO-FFI (calculated $\alpha$-values for the individual factors: $\alpha_{\text {Power }}=0.81, \alpha_{\text {Retention }}=0.78, \alpha_{\text {Distrust }}=0.77$, $\alpha_{\text {Anxiety }}=0.43, \alpha_{\text {Neuroticism }}=0.74, \alpha_{\text {Extraversion }}=0.68, \alpha_{\text {Openness }}=0.78, \alpha_{\text {Agreeableness }}=0.77$, $\alpha_{\text {Conscientiousness }}=0.82$ ).

\section{RESULTS}

\section{NEO-FFI results}

Table 1 shows the means, standard deviations and minimum/maximum values of the NEO-FFI. Twelve items per dimension (60 in total) on a five-point Likertscale generated scores ranging from 60 to 300 points maximum (12 points $\min . / 60$ points max. for each dimension):

Table 1. NEO-FFI descriptive results

\begin{tabular}{ccccc}
\hline NEO-FFI Factor & $\boldsymbol{M}$ & $\boldsymbol{S D}$ & Minimum & Maximum \\
\hline Neuroticism & 17.67 & 6.74 & 6 & 37 \\
Extraversion & 31.57 & 5.04 & 16 & 40 \\
Openness to Experience & 29.42 & 6.67 & 13 & 44 \\
Agreeableness & 33.45 & 5.74 & 19 & 43 \\
Conscientiousness & 37.10 & 6.03 & 21 & 47 \\
\hline
\end{tabular}

Source: Author's results.

Higher means were found for four factors $\left(M_{\text {Conscientiousness }}=37.10\right.$, $M_{\text {Agreeableness }}=33.45, M_{\text {Extraversion }}=31.57 M_{\text {Openness }}=29.42$ ), while the mean for neuroticism $\left(M_{\text {Neuroticism }}=17.67\right)$ was significantly lower. The $S D$ values of the factors were located within a relatively small range $(S D=$ from 5.04 to 6.74$)$. 


\section{MAS results}

Table 2 presents the descriptive results of the MAS. Based on the five-point Likert scale, the participants could obtain scores from $29 \mathrm{~min}$. to 145 points max.:

Table 2. MAS descriptive results

\begin{tabular}{ccccc}
\hline MAS Factor & $\boldsymbol{M}$ & $\boldsymbol{S D}$ & Minimum & Maximum \\
\hline Power-Prestige & 17.42 & 5.44 & 9 & 29 \\
Retention-Time & 26.23 & 4.60 & 13 & 35 \\
Distrust & 18.52 & 4.68 & 7 & 31 \\
Anxiety & 15.90 & 3.22 & 9 & 22 \\
\hline
\end{tabular}

Source: Author's results.

Higher means appeared for retention-time $\left(M_{\text {Retention }}=26.23\right)$, while lower values for the other factors $\left(M_{\text {Distrust }}=18.52, M_{\text {Power }}=17.42, M_{\text {Anxiety }}=15.90\right)$ were revealed. The MAS $S D$ values ranged from $3.22\left(S D_{\text {Anxiety }}\right)$ to $5.44\left(S D_{\text {Power }}\right)$.

\section{Multiple linear regression results}

Multiple linear regression analysis determined the variance for the MAS factors explained by the NEO-FFI factors, gender, age, net income, total budget, and household wealth. The Kolmogorov-Smirnov and the Shapiro-Wilk test (both with $p$-values $>0.05$ in most cases) indicated normally distributed data, thus sufficient conditions for regression analysis. Table 3 shows the most significant regression models for each MAS factor:

Table 3. Linear regression results for each MAS factor

\begin{tabular}{ccccccccr}
\hline & \multicolumn{8}{c}{$\begin{array}{c}\text { Variable } \\
\boldsymbol{\beta} \text { weight } \\
\text { (p-value) }\end{array}$} \\
\cline { 2 - 7 } MAS Factor & $\mathbf{1}$ & $\mathbf{2}$ & $\mathbf{3}$ & $\mathbf{4}$ & $\mathbf{5}$ & $\mathbf{6}$ & $\mathbf{7}$ & R2 \\
\cline { 2 - 7 } Power- & Neurot. & Extrav. & Openn. & Agreea. & Consc. & Gender & \\
Prestige & 0.16 & 0.06 & $-0.23^{*}$ & $-0.32^{* *}$ & -0.03 & $-0.26^{*}$ & 0.24 \\
& $(0.222)$ & $(0.610)$ & $(0.033)$ & $(0.004)$ & $(0.783)$ & $(0.027)$ & \\
Retention- & Neurot. & Extrav. & Openn. & Agreea. & Consc. & Gender & \\
Time & -0.08 & -0.003 & -0.02 & -0.07 & 0.19 & 0.23 & 0.11 \\
& $(0.542)$ & $(0.979)$ & $(0.880)$ & $(0.519)$ & $(0.138)$ & $(0.067)$ &
\end{tabular}




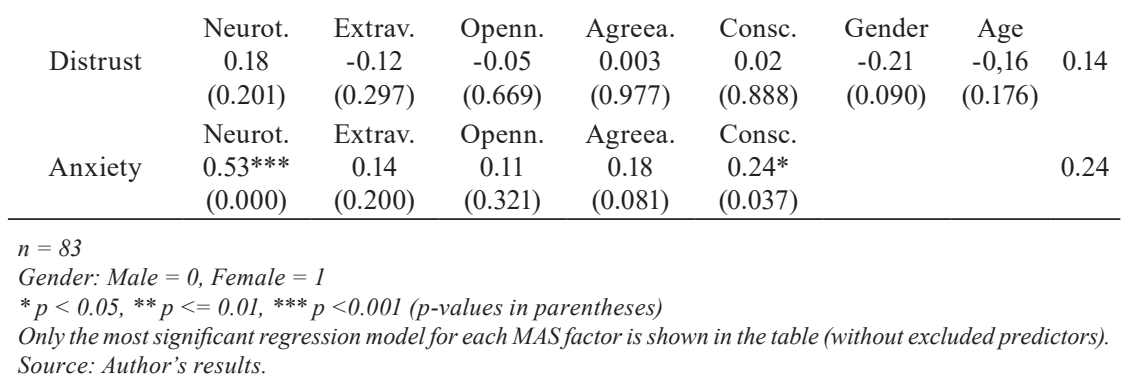

The model for power-prestige indicated a highly significant outcome $\left(p_{\text {Power }}=0.001\right)$ by explaining $18.4 \%$ of total variance using the independent variables openness to experience, agreeableness, and (male) gender $\left(\beta_{\text {Openness }}=0.231^{*}, p_{\text {Openness }}=0.033 ; \beta_{\text {Agreeableness }}=0.316^{* *}, p_{\text {Agreeableness }}=0.004\right.$; $\left.\beta_{\text {Gender }}=0.259^{*}, p_{\text {Gender }}=0.027\right)$. For anxiety, a highly significant model $\left(p_{\text {Anxiety }}=0.001\right)$ explaining $19.3 \%$ of the total variance through neuroticism and conscientiousness was found $\left(\beta_{\text {Neuroticism }}=0.530^{* * *}, p_{\text {Neuroticism }}=0.000\right.$; $\left.\beta_{\text {Conscientiousness }}=0.237^{*}, p_{\text {Conscientiousness }}=0.037\right)$. None of the tested regression models for the dependent retention-time and distrust dimensions indicated significant relationships (lowest $p_{\text {Retention }}=0.149, R_{\text {Retention }}^{2}=4.4 \%$; lowest $p_{\text {Distrust }}=0.110$, $R_{\text {Distrust }}^{2}=6.0 \%$ ). Extraversion, age, net income, total budget, and household wealth did not show any predictive power in relation to money attitudes either.

\section{Comparison of Results}

Table 4 compares the NEO-FFI results (means) with the German population-representative NEO-FFI-sample $(n=871)$ and a comparable sample group $(n=77)$ of Austrian business education graduates (Borkenau - Ostendorf 2008; Nowak - Pani 2013):

Table 4. NEO-FFI comparison of results (with NEO-FFI-sample and Austrian study)

\begin{tabular}{cccc}
\hline NEO-FFI Factor & $\begin{array}{c}\text { Austrian } \\
\text { Study 2017 } \boldsymbol{M}\end{array}$ & $\begin{array}{c}\text { Austrian } \\
\text { Study 2013 } \boldsymbol{M}\end{array}$ & $\begin{array}{c}\text { German NEO-FFI-sample 2008 } \\
\text { (Population-representative) } \boldsymbol{M}\end{array}$ \\
\hline Neuroticism & 17.67 & 12.12 & 20.99 \\
Extraversion & 31.57 & 32.22 & 26.88 \\
Openness to & 29.42 & 30.35 & 29.47 \\
Experience & 33.45 & 35.91 & 30.45 \\
Agreeableness & 37.10 & 40.04 & 32.61 \\
Conscientiousness & & & \\
\hline
\end{tabular}

Source: Author's results and data adapted from Borkenau-Ostendorf 2008; Nowak-Pani 2013. 
In the German population-representative sample, participants showed more neurotic personalities (+ 3.32 points) and lower values for extraversion (-4.69), agreeableness (-3.00), and conscientiousness (-4.49). Only slight differences were found in comparison with the Austrian study of 2013 with the exception of the neuroticism mean values (-5.55 lower in the comparison study).

In addition, the MAS results of this study were compared to an US-study $(n=224)$ that used a sample of bicultural college students (Chi - Banerjee 2013) in Table 5:

Table 5. MAS results comparison (with US-study)

\begin{tabular}{ccc}
\hline MAS Factor & Austrian Study 2017 & US Study 2013 \\
& $\boldsymbol{M}$ & $\boldsymbol{M}$ \\
\hline Power-Prestige & 17.42 & 18.58 \\
Retention-Time & 26.23 & 22.89 \\
Distrust & 18.52 & 20.47 \\
Anxiety & 15.90 & 18.07 \\
\hline
\end{tabular}

Source: Author's results and data adapted from Chi-Banerjee 2013.

The results in this study agree well with those of the comparable study; yet it is remarkable that the Austrian students in this sample were more strongly focused on future-oriented retention-time $(+3.34)$ and less on anxiety-oriented $(-2.17)$ money attitudes, possibly as a result of the different sample compositions and cultural backgrounds.

\section{DISCUSSION}

The aim of this article was to investigate if personality traits or biographical variables predict money attitudes. In Figure 1, the significant multiple linear regression results are summarized.

The results for power-prestige suggest that experience-opened and agreeableness-oriented personalities focus less on the power-prestige dimension of money. Those individuals tend less to use money to influence and impress other people. Moreover, males (in contrast to females) rather perceive money as an instrument for showing power-prestige, a finding which is well supported by past studies (Chi - Banerjee 2013; Furnham 1984; Furnham - Okamura 1999; Medina et al. 1996).

Regarding anxiety, the results indicate that individuals with a neurotic and a conscientious personality structure rather recognize money as a source of 
anxiety as well as a source of anxiety protection, supporting the results of an earlier study about credit card debt (Brown - Taylor 2014). Certain MAS items measure the function of money as a source of anxiety protection (BlaszczynskiNower 2010): For example, one MAS item asks if a participant becomes nervous in the case of a lack of money (Yamauchi - Templer 1982). Thus, having enough money at their disposal reduces anxiety-related feelings (like nervousness) for such individuals.

Figure 1. Multiple linear regression results - overview

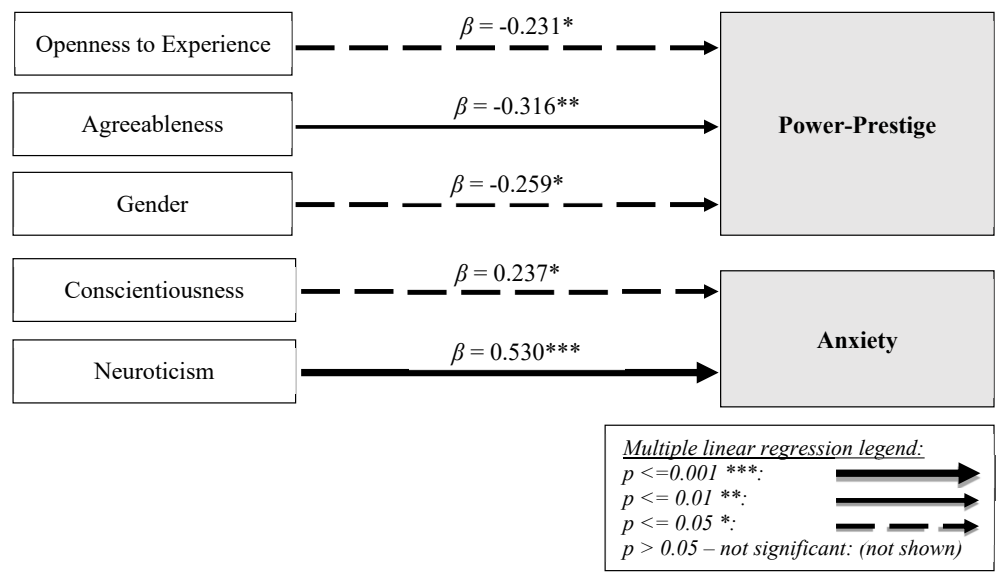

Two partially conflicting perspectives (consumer and business) can be derived from the study results. One consumer implication concerns awareness about individually harmful financial behavior: Pronounced openness to experience and low anxiety personalities, as well as male gender, suggest a power-prestige-oriented money attitude. The presence of these predictors indicates a perception of money that could lead to problematic financial behavior like purchasing unaffordable luxury goods or excessive indebtedness. Also, less pronounced money dimensions, particularly retention-time, might potentially lead to problematic behavior such as not starting an adequate private pension. Therefore, developing awareness about individual risk factors (through an evaluation of predictors of money attitude from an individual viewpoint) and people's own money attitude framework could lead to more sustainable individual financial behavior.

For business purposes, sales and marketing strategies could be developed based on customer-specific money attitudes or on relevant predictors of money attitudes. This, most obviously, already seems to be the case in the finance 
industry. For example, marketing activities related to consumer credit or investment products are oriented towards individuals with different money attitudes. Additionally, predictive factors (e.g. gender, certain personality traits) could be included in marketing strategies.

An unexpected implication of this study may be the characterization of a business-education-teacher personality, which is less neurotic and more extrovert, agreeable and conscientious compared to that of the average citizen.

There exist, however, some limitations of this study. Even though welltested and broadly accepted scientific tests were used, the instruments have limited explanatory power. The factor analysis indicated that about one-third of a personality can be explained through the NEO-FFI factors (Borkenau Ostendorf 2008). Additionally, the MAS factors comprise about $33.60 \%$ of the explanatory power of total variance (Yamauchi - Templer 1982). The relatively homogeneous business education student sample cannot be considered representative of the Austrian population. Student samples (of different study directions) were used in most comparable studies (Baker - Hagedorn 2008), which allow comparison to a certain extent. The relatively small sample size might affect the robustness of the multiple linear regression results, as power analysis results suggest a minimum sample size of about 90 to 100 participants for this study design (Hemmerich 2020). Moreover, all significant multiple linear regression models (adjusted $R^{2}$ values) explain less than $20.0 \%$ of the total variance of the particular dependent variable (power-prestige, anxiety), leaving about $80.0 \%$ of the influence unverified. Other empirical evidence suggests the existence of additional independent factors such as work background, socioeconomic- and educational level, geographical origin, as well as social, political and religious values (Medina et al. 1996).

\section{CONCLUSION}

Studies in various countries show the influence of personality traits and biographical variables on money attitude factors, while comparable research results for Austria are scarce. In this Austrian study, individuals who high scored in the power-prestige dimension tended to recognize money as an instrument for impressing and influencing other people; for them, money embodies a symbol of success (Yamauchi - Templer 1982). Males and individuals with a less experience-opened and less agreeable personality focused more strongly on the power-prestige dimension of money. In contrast, neurotic and high conscientious personalities showed distinct anxiety-oriented money attitudes. 
The Austrian study results partly confirm outcomes from other parts of the world; i.e. that males tend to focus more strongly on the power-prestige dimension than females (Chi - Banerjee 2013; Furnham 1984; Furnham - Okamura 1999; Medina et al. 1996), and conscientious individuals tend to show anxiety-related money attitudes (Brown - Taylor 2014). Causal relationships between financerelated independent factors (i.e. net income, total budget, household wealth) and money attitudes, in contrast to other study results (Furnham 1984; Roberts Sepulveda 1999), could not be verified.

Future research should examine the role of the additional money attitude predictors which have been identified in other studies, or which are still unidentified. Replicating the study in Austria using larger and different sample groups (e.g. employees from different sectors or retirees) could strengthen the results of this study and uncover additional causal relationships. Further longitudinal studies could provide insights into changes in individual money attitudes over time.

\section{REFERENCES}

Adelt, Peter - Bert Feldmann (2017), "Spar- und Anlageentscheidungen älterer Menschen,“ in: Fischer, Lorenz - Thomas Kutsch - Sephan Ekkehard, eds., Finanzpsychologie, Berlin, Boston, Oldenbourg Wissenschaftsverlag, pp. 250-272. https://permalink.obvsg.at/wuw/ AC02521286.

Ajzen, Icek - Martin Fishbein (2014), "The influence of attitudes on behavior," in: Albarracin, Dolores - Blair Johnson - Mark Zanna, eds., The Handbook of Attitudes, New York, London, Psychology Press, pp. 173-221. https://permalink. obvsg.at/wuw/AC04680715.

Albarracin, Dolores - Blair Johnson - Mark Zanna - Tarcan Kumkale (2014), "Attitudes: Introduction and scope," in: Albarracin, Dolores - Blair Johnson Mark Zanna, eds., The Handbook of Attitudes, New York, London, Psychology Press, pp. 3-19. https:// permalink.obvsg.at/wuw/ AC04680715.

Allport, Gordon (1935), "Attitudes," in: Murchison, Carl, ed., A Handbook of Social Psychology, London, Worcester, Oxford University Press, pp. 798-844.

Baker, Paul Morgen - Robert Hagedorn (2008), "Attitudes to money in a random sample of adults: Factor analysis of the MAS and MBBS scales, and correlations with demographic variables", The Journal of SocioEconomics Vol. 37, No 5, pp. 1803-1814. https://doi.org/ 10.1016/j.socec.2008.02.004.

Belk, Russel (1985), "Materialism: Trait aspects of living in the material world", Journal of Consumer Research Vol. 12, No 3, p. 265. https://doi. org/10.1086/208515. 
Blaszczynski, Alex - Lia Nower (2010), "Instrumental tool or drug: Relationship between attitudes to money and problem gambling", Addiction Research and Theory Vol. 18, No 6, pp. 681-691. https://doi. org/10.3109/16066351003786752.

Borkenau, Peter - Fritz Ostendorf (2008), NEO-Fünf-Faktoren-Inventar nach Costa und McCrae. Manual. Renormed and fully revised $2^{\text {nd }}$ Edition, Göttingen, Hogrefe.

Brown, Sarah - Karl Taylor (2014), "Household finances and the 'Big Five' personality traits", Journal of Economic Psychology Vol. 45, pp. 197-212. https://doi.org/10.1016/ j.joep.2014.10.006.

Chi, Yeong Nain - Gaurango Banerjee (2013), "Empirical analysis of bicultural border college students' attitudes toward money", Journal of Applied Business and Economics Vol. 14, No 3, pp. 70-82.

Donnelly, Grant - Ravi Iyer - Ryan Howell (2012), "The Big Five personality traits, material values, and financial well-being of self-described money managers", Journal of Economic Psychology Vol. 33, No 6, pp. 1129-1142. https://doi.org/10.1016/j.joep.2012.08.001.

Engelberg, Elisabeth - Lennart Sjöberg (2006), "Money attitudes and emotional intelligence", Journal of Applied Social Psychology Vol. 36, No 8, pp. 2027-2047. https://doi.org/ 10.1111/j.0021-9029.2006.00092.x.

Fazio, Russel (1990), "Multiple processes by which attitudes guide behavior: The MODE model as an integrative framework", Advances in Experimental Social Psychology Vol. 23, pp. 75-109. https://permalink.obvsg.at/wuw/ AC00421217.

Fazio, Russel - Michael Olson (2014), “The MODE model: Attitude-behavior processes as a function of motivation and opportunity", in: Sherman, Jeffrey Bertram Gawronski - Yaacov Trope, eds., Dual-Process Theories of the Social Mind, New York, Guilford Publications, pp. 155-171.

Martin, Fishbein - Icek Ajzen (1975), Belief, Attitude, Intention and Behavior: An Introduction to Theory and Research, Reading, Addison-Wesley. https://oi. org/10.2307/2065853.

Furnham, Adrian (1984), "Many sides of the coin: The psychology of money usage", Personality and Individual Differences Vol. 5, No 5, pp. 501-509. https:// doi.org/ 10.1016/0191-8869(84)90025-4.

Furnham, Adrian - Michael Argyle (2013), The Psychology of Money, Hoboken, Taylor and Francis. https://doi.org/10.4324/9781315812496.

Furnham, Adrian - Bruce Kirkcaldy - Richard Lynn (1994), "National attitudes to competitiveness, money, and work among young people: First, second, and third world differences", Human Relations Vol. 47, No 1, pp. 119132. https://doi.org/10.1177/ 001872679404700106. 
Furnham, Adrian - Ryo Okamura (1999), "Your money or your life: Behavioral and emotional predictors of money pathology", Human Relations Vol. 52, No 9, pp. 1157-1177. https://doi.org/10.1177/001872679905200903.

Furtner, Reinhard (2017), Personality Traits and Money Attitude. A Quantitative Empirical Study or why you Invested your Capital in Mutual Funds while your Neighbor bought a Brand-new Porsche Sportscar, Master thesis, Vienna, Vienna University of Economics and Business. https://permalink. obvsg.at/wuw/AC15003550.

Günther, Thomas - Martin Detzner (2009), "Risikoverhalten von Managern: Ergebnisse empirischer Controllingforschung“, CFO aktuell Vol. 3, No 3, p. 127. https://katalog. wu.ac.at/permalink/f/1lnoe4e/TN_gbv607708840.

Hanashiro, Rieko - Diane Masuo - Jung Hoon Kim - Lakshmi Malroutu (2004), "Money attitudes and gender comparison between Japanese students and Asian American students", The Okinawan Journal of American Studies Vol. 1, pp. 38-45. http://hdl. handle.net/ 20.500.12000/6773.

Hanley, Alice - Mari Wilhelm (1992), "Compulsive buying: An exploration into self-esteem and money attitudes", Journal of Economic Psychology Vol. 13, No 1, pp. 5-18. https://doi. org/10.1016/0167-4870(92)90049-d.

Harari, Yuval Noah (2017), The Capitalist Religion, https://www.ynharari. com/topic/money-and-politics, accessed 07 Oct 2019.

Harrison, Tina (1994), "Mapping customer segments for personal financial services", International Journal of Bank Marketing Vol. 12, No 8, pp. 17-25. https://doi.org/ 10.1108/02652329410069010.

Hemmerich, Wanja (2020), Poweranalyse und Stichprobenberechnung für Regression: StatistikGuru, https://statistikguru.de/rechner/poweranalyseregression.html, accessed 06 Jan 2020.

Jhang, Fang-Hua (2018), "The five dimensions of money attitudes and their link to changes in life satisfaction among Taiwanese adolescents in poverty", Applied Research Quality Life Vol. 13, No 2, pp. 399-418. https://doi.org/10.1007/ s11482-017-9531-x.

Kahneman, Daniel (2003), "Maps of bounded rationality: Psychology for behavioral economics", The American Economic Review Vol. 93, No 5, pp. 1449-1475. https://doi.org/ 10.1257/000282803322655392.

Krueger, David (1986), "Money, success, and success phobia", in: Krueger, David, ed., The Last Taboo. Money as Symbol and Reality in Psychotherapy and Psychoanalysis. New York, Brunner/Mazel, pp 3-16. https://doi.org/10.1176/ ps.38.1.84.

Lau, Sing (1998), "Money: What it means to children and adults", Social Behavior and Personality, Vol. 26, No 3, pp. 297-306. https://doi.org/10.2224/ sbp.1998.26.3.297. 
Li, Dongjin - Ying Jiang - Shenghui An - Zhe Shen - Wenji Jin (2009): "The influence of money attitudes on young Chinese consumers" compulsive buying", Young Consumers Vol. 10, No 2, pp. 98-109. https://doi. org/10.1108/17473610910964688.

Lim, Vivien - Teo Thompson (1997): "Sex, money and financial hardship: An empirical study of attitudes towards money among undergraduates in Singapore", Journal of Economic Psychology Vol. 18, No 4, pp. 369-386. https:// doi.org/10.1016/s0167-4870(97)00013-5.

Lim, Vivien - Teo Thompson - Geok Leng Loo (2003): "Sex, financial hardship and locus of control: An empirical study of attitudes towards money among Singaporean Chinese", Personality and Individual Differences Vol. 34, No 3, pp. 411-429. https://doi.org/10.1016/ s0191-8869(02)00063-6.

McClelland, David (1967), "Money as a motivator: Some research insights", The McKinsey Quarterly Vol. 4, No 2, pp. 10-21. https://permalink.obvsg.at/ wuw/(CKB)954921364521.

McCrae, Robert - Paul Costa (2008), "A five-factor theory of personality", in: John, Oliver - Robins Richard - Lawrence Pervin, eds., Handbook of Personality: Theory and Research, $3^{\text {rd }}$ Edition, Vol 2, New York, The Guilford Press, pp. 159-181. https://permalink.obvsg.at/ wuw/AC09377542.

McCrae, Robert - Oliver John (1992), "An introduction to the five-factor model and its applications", Journal of Personality Vol. 60, No 2, pp. 175-215. https://doi.org/10.1111/ j.1467-6494.1992.tb00970.x.

Medina, Jose - Joel Saegert - Alicia Gresham (1996), "Comparison of MexicanAmerican and Anglo-American attitudes toward money", Journal of Consumer Affairs Vol. 30, No 1, pp. 124-145. https://doi.org/10.1111/j.1745-6606.1996.tb00728.x.

Mitchell, Terence - Amy Mickel (1999), "The meaning of money: An individual-difference perspective", The Academy of Management Review Vol. 24, No 3, pp. 568-578. https:// doi.org/10.5465/amr.1999.2202138.

Mohamad, Fazli Sabri - Celia, Hayhoe - Lay Goh (2006), "Attitudes, values and belief towards money: Gender and working sector comparison", Pertanika Journal of Social Sciences and Humanities Vol. 14, No 2, pp. 121-130. http:// www.pertanika.upm.edu.my/Pertanika \%20PAPERS/JSSH\%20Vol.\%2014\%20 (2)\%20Sep.\%202006/04\%20JSSH\%20Vol.14\%20(2)\%202006\%20(Pg\%20111119).pdf.

Müller, Horst (1995), „Zur Risikobereitschaft privater Geldanleger“, Kredit und Kapital Vol. 28, No 1, pp. 134-160. https://permalink.obvsg.at/wuw/ (CKB)110978976474931.

Nowak, Denise - Viola Pani (2013), Lehrer/innen-Persönlichkeit und ihre Auswirkungen auf die Leistungen der Schüler/innen, Master thesis, Vienna, Vienna University of Economics and Business. https://permalink.obvsg.at/wuw/AC11110498. 
Ratnawat, Ramgopal - Sachin Borgave (2019), "Impact of BigFive personality on impulsive buying behaviour", International Journal of Multidisciplinary Research Review Vol. 4, No 6, pp. 500505.

Roberts, James - Eli Jones (2001), "Money attitudes, credit card use, and compulsive buying among American college students", Journal of Consumer Affairs Vol. 35, No 2, pp. 213240. https://doi.org/10.1111/j.1745-6606.2001. tb00111.x.

Roberts, James - Cesar Sepulveda (1999), "Demographics and money attitudes: A test of Yamauchi and Templers (1982) money attitude scale in Mexico", Personality and Individual Differences, Vol. 27, No 1, pp. 19-35. https://doi.org/10.1016/s0191-8869(98)00241-4.

Rubinstein, Carin (1981), "Money and self-esteem, relationships, secrecy, envy, satisfaction", Psychology Today Vol. 15, No 5, pp. 29-44.

Six, Bernd (2009), "Attitudes", in: Dorsch, Friedrich - Hartmut Häcker, Kurt Stapf, Christian Becker-Carus, eds., Dorsch psychologisches Wörterbuch, $15^{\text {th }}$ Reviewed and extended Edition, Bern, Huber, p. 247. https://permalink. obvsg.at/wuw/AC02240890.

Sommer, Rudolf(2007), Consumer's Mind-Die Psychologie des Verbrauchers, Reihe Edition Horizont, Frankfurt am Main, Deutscher Fachverlag. https:// permalink.obvsg.at/wuw/ AC05779406.

Statistik Austria - Bundesanstalt Statistik (2017), Nettomonatseinkommen unselbständig Erwerbstätiger nach sozioökonomischen Merkmalen Jahresdurchschnitt2017,https://www.statistik.at/web_de/statistiken/menschen und_gesellschaft/soziales/personen-einkommen/nettomonatseinkommen/ index.html, accessed 07 Oct 2019.

Taneja, Rimple Manchanda (2012), "Money attitude-an abridgement", Researchers World Vol. 3, No 3, p. 94. http://www.researchersworld.com/vol3/ issue3/vol3_issue3_3/ Paper_12.pdf.

Tang, Thomas Li-Ping (1992), "The meaning of money revisited", Journal of Organizational Behavior Vol. 13, No 2, pp. 197-202. https://doi.org/10.1002/ job.4030130209.

Wärneryd, Karl Erik (2001), Stock-market psychology. How people value and trade stocks, Cheltenham, Elgar. https://permalink.obvsg.at/wuw/AC03258679.

Wong, Alan - Bernardo Carducci (1991), "Sensation seeking and financial risk taking in everyday money matters", Journal of Business and Psychology Vol. 5, No 4, pp. 525-530. https://doi.org/10.1007/bf01014500.

Yamauchi, Kent - Donald Templer (1982), "The development of a Money Attitude Scale", Journal of Personality Assessment Vol. 46, No 5, pp. 522-528. https://doi.org/10.1207/ s15327752jpa4605_14. 


\section{APPENDIX A}

Table 6. Biographical factors as predictors of money attitudes

\begin{tabular}{|c|c|}
\hline Study & Results \\
\hline $\begin{array}{l}\text { Furnham } 1984 \\
\text { Great Britain } \\
(\mathrm{n}=256) \\
\text { MBBS }\end{array}$ & $\begin{array}{l}\text { Gender and Protestant work ethic beliefs influence money } \\
\text { obsession and beliefs regarding effort/ability in relation to } \\
\text { obtaining money. Females who display a Protestant work ethic } \\
\text { beliefs tend to show higher money obsession and higher ability/ } \\
\text { effort scores. } \\
\text { Low-income individuals relate money accumulation less to effort/ } \\
\text { ability. Those individuals tend also not to perceive money as a tool } \\
\text { for influencing others and they are less obsessed with money. } \\
\text { Better educated females show a more conservative and retentive } \\
\text { money attitude. }\end{array}$ \\
\hline Furnham-Okamura & $\begin{array}{l}\text { Women avoid moral risks regarding money. Also, women tend to } \\
\text { believe that money is not made only through chance. }\end{array}$ \\
\hline $\begin{array}{l}\text { Great Britain } \\
(n=267)\end{array}$ & $\begin{array}{l}\text { Men perceive money in a more materialistic way and less } \\
\text { negatively than women. }\end{array}$ \\
\hline $\begin{array}{l}\text { Money Pathology Scales } \\
\text { (among other scales) }\end{array}$ & $\begin{array}{l}\text { Religious people believe that money is obtained through hard work } \\
\text { and ability. Furthermore, they avoid moral risks regarding money. }\end{array}$ \\
\hline Chi-Banerjee 2013 & Females show a more anxious and worrisome attitude to money. \\
\hline $\begin{array}{l}\text { United States } \\
(n=224) \\
M A S\end{array}$ & $\begin{array}{l}\text { Moreover, for female study participants it was harder to pass up a } \\
\text { sale. } \\
\text { Differences were found between department store shopping } \\
\text { (influenced by anxiety) and online shopping (influenced by power- } \\
\text { prestige). }\end{array}$ \\
\hline $\begin{array}{l}\text { Roberts-Sepulveda } 1999 \\
\text { Mexico } \\
(\mathrm{n}=274), \text { MAS }\end{array}$ & $\begin{array}{l}\text { The money attitude factor power-prestige is influenced by age and } \\
\text { occupation. Younger people and unemployed study participants } \\
\text { tend to perceive money as a tool for influencing and impressing } \\
\text { others. } \\
\text { High-income individuals and better educated individuals rather } \\
\text { concentrate on financial future planning. } \\
\text { Older study participants show more money anxiety. }\end{array}$ \\
\hline $\begin{array}{l}\text { Hanashiro et al. } 2004 \\
\text { United States/Japan } \\
(\mathrm{n}=208+170) \\
\text { MBBS }\end{array}$ & $\begin{array}{l}\text { Cultural differences (between Asian American and Japanese } \\
\text { people) and gender differences were found: } \\
\text { Money attitudes are formed in relation to other people and money } \\
\text { is closely linked to personality and power (Asian Americans). } \\
\text { Japanese study participants showed a stronger saving attitude. } \\
\text { Males focus on the power dimension of money and they value } \\
\text { money more. Females rather concentrate on the saving dimension } \\
\text { of money. }\end{array}$ \\
\hline $\begin{array}{l}\text { Medina et al. } 2004 \\
\text { United States } \\
(\mathrm{n}=6,863), \text { MAS }\end{array}$ & $\begin{array}{l}\text { Cultural differences (between Mexican-Americans and Anglo- } \\
\text { Americans) were investigated: } \\
\text { Anglo-Americans show higher values regarding the retention-time } \\
\text { and quality factors. No differences were identified regarding the } \\
\text { power-prestige, distrust, and anxiety factors. }\end{array}$ \\
\hline
\end{tabular}




\begin{tabular}{ll}
\hline Sabri et al. 2006 & Differences between gender and government/private work sector \\
Malaysia & were analyzed: \\
$(\mathrm{n}=120)$ & Private sector workers connect money with power and high social \\
MBBS & status. \\
& Governmental employees score higher in the retention dimension. \\
& Furthermore, they showed a more cautious money attitude. \\
& Males tend to focus on the power dimension of money attitude. \\
\hline
\end{tabular}

Source: Adapted from Chi-Banerjee 2013; Furnham 1984; Furnham - Okamura 1999; Hanashiro et al. 2004; Medina et al. 1996; Roberts - Sepulveda 1999; Sabri et al. 2006.

\section{APPENDIX B}

Table 7. Personality factors as predictors of money attitudes

\begin{tabular}{|c|c|}
\hline Study & Results \\
\hline $\begin{array}{l}\text { Lau } 1998 \\
\text { China ( } 3 \text { studies) } \\
(\mathrm{n}=378, \mathrm{n}=467, \mathrm{n}= \\
1463)\end{array}$ & $\begin{array}{l}\text { Money attitudes are developed through socialization. Children } \\
\text { of a young age (five or six years old) do not yet connect money to } \\
\text { attitudes. Later, moralistic and evaluative components are linked } \\
\text { to money. } \\
\text { Personal characteristics (especially values) influence the money } \\
\text { attitudes of an individual. }\end{array}$ \\
\hline $\begin{array}{l}\text { Hanley - Wilhelm } 1992 \\
\text { United States } \\
(n=100+43)\end{array}$ & $\begin{array}{l}\text { Differences between normal customers and compulsive spenders } \\
\text { were analyzed: } \\
\text { Normal customers show higher self-esteem values and they focus } \\
\text { on the security dimension of money. On the contrary, compulsive } \\
\text { spenders score higher in the money obsession, power, retention, } \\
\text { and inadequacy dimensions. }\end{array}$ \\
\hline $\begin{array}{l}\text { Brown - Taylor } 2014 \\
\text { Great Britain } \\
(n=2595+1966)\end{array}$ & $\begin{array}{l}\text { The relationship between personality traits and household finances } \\
\text { was investigated between a group of single- and a group of couple } \\
\text { households: } \\
\text { Extraverted persons rather tend to hold shares. Also, extraverted } \\
\text { people in the sample group showed a tendency to hold credit card } \\
\text { debt. On the contrary, money-conscious people rather avoid credit } \\
\text { card debt. } \\
\text { A high agreeableness personality score is linked with a higher } \\
\text { probability of owning shares. }\end{array}$ \\
\hline $\begin{array}{l}\text { Wong-Carducci } 1991 \\
\text { United States } \\
(\mathrm{n}=233)\end{array}$ & $\begin{array}{l}\text { The general personal risk attitude was investigated in this study: } \\
\text { High-risk seekers also show high-risk behavior in relation to } \\
\text { everyday money matters. }\end{array}$ \\
\hline $\begin{array}{l}\text { Furnham - Okamura } \\
1999 \\
\text { Great Britain } \\
(\mathrm{n}=256)\end{array}$ & $\begin{array}{l}\text { Especially negative emotions (helplessness, depression, fear, } \\
\text { anxiety) are linked with money. } \\
\text { Negative money emotions tend to cause money pathologies. }\end{array}$ \\
\hline
\end{tabular}




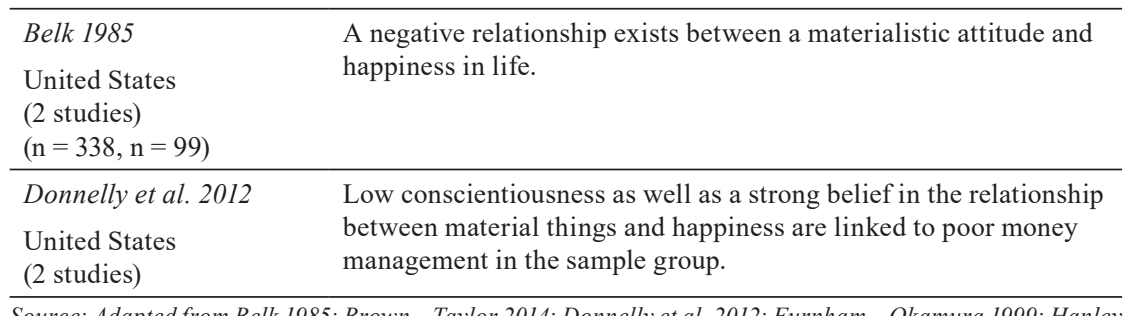

Source: Adapted from Belk 1985; Brown-Taylor 2014; Donnelly et al. 2012; Furnham-Okamura 1999; Hanley 1992; Lau 1998; Wong-Carducci 1991. 
